\title{
A FRATERNIDADE NA POLÍTICA
}

\author{
LA FRATERNIDAD EN LA POLÍTICA
}

Tradução em Libras por LIMA, N. G do discurso de LUBICH, Chiara Fraternità in politica, Barcelona, 2002.

Acesso através do link:

https://www.youtube.com/watch?v=kvEKCwutGA4\&t=11s

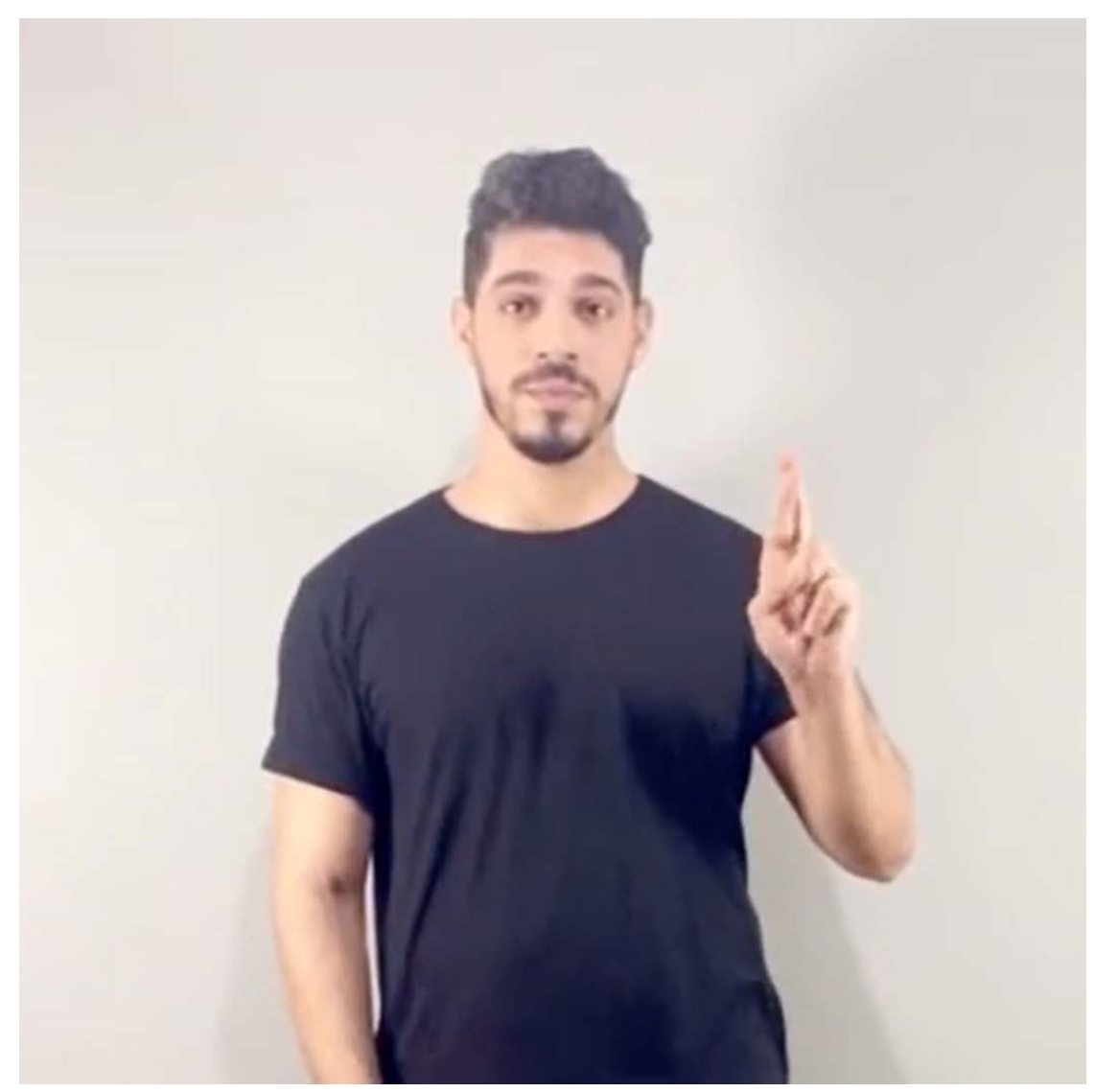

